\title{
TITLE:
}

\section{ON SOME NEW OR LITTLE KNOWN CORALS FROM JAPAN AND AUSTRALIA}

AUTHOR(S):

Eguchi, Moroki

CITATION:

Eguchi, Moroki. ON SOME NEW OR LITTLE KNOWN CORALS FROM JAPAN AND AUSTRALIA. PUBLICATIONS OF THE SETO MARINE BIOLOGICAL LABORATORY 1973, 20: 81-87

ISSUE DATE:

1973-12-19

URL:

http://hdl.handle.net/2433/175788

RIGHT: 


\title{
ON SOME NEW OR LITTLE KNOWN CORALS FROM JAPAN AND AUSTRALIA
}

\author{
Motokı EGUCHI
}

The Sabiura Laboratory of the Marine Park Center, Kushimoto, Wakayama-ken and Tokyo Kasei Daigaku, 18 Kaga-1, Itabashi-ku, Tokyo

\section{With Plate I and 2 Text-figures}

While being engaged in observations of coral fauna in Japanese Marine Park areas, the writer has become aware of the existence of some undescribed species of Scleractinian corals in Japan and that the distribution of hermatypic corals has been extended more northwards than formerly known, up to about $35^{\circ} \mathrm{N}$ in the Korean Strait. In addition, two ahermatypic corals from the Investigator Strait, Southern Australia collected by Mrs. J.E. WATSON are also briefly described and shown in photographs on this occasion.

The new species were collected from the vicinity of the Kushimoto Marine Park and the waters around Izu Penninsula, Shizuoka Prefecture, mostly from shallow floors but one.

The writer expressed his cordial thanks to those who collected the specimens, offered them to writer's examination or cooperated or aided the writer in carrying out the present study: Mrs. J.E. Watson of the Melbourne Museum, Victoria, Mr. K. SuzuKI of the Marine Science Museum, Tokai University and his collaborators, and Mr. T. TATsuki of the Sabiura Laboratory of the Marine Park Center, Kushimoto, Wakayama Prefecture.

\section{Description of Species from Japan \\ Order SCLERACTINIA BOURNE \\ Suborder FUNGIINA DUNCAN \\ Family PORITIDAE GRAY \\ Genus Alveopora Blainville}

Genotype; Alveopora daedalea (ForSKஷ̀L)

\section{Alveopora japonica EGUGHI var. magna $\mathrm{n}$.}

(P1. I, Fig. 4)

Corallum massive, rounded, $73 \times 35 \mathrm{~mm}$ in size; originally formed of encrusting thin colonies. Corallites polygonal in shape, often 2 or 3 calices in a series, like meandroid form. Wall perforated, diameter of calice $4-5 \mathrm{~mm}$ or rarely $6 \mathrm{~mm}$. Septa 
spiny; horizontal spines projecting inward from shieve like mural trabeculae and arrange in two cycles of hexameral plan. Epitheca thin, but complete, with concentric rings along the margin of lower surface of corallum. Polyps of living form with greenish protruding 12 long subcylindrical or club-shaped tentacles, ring along the margin of oral disc.

Remarks: Formerly the writer treated the form as a variation of Alveopora japonica (EGUCHI, 1968, p. C 19) ${ }^{1}$; the present variety is easily distinguishable from the typical species by its larger calices. The diameter of corallites in typical $A$. japonica varies in the range of $2.5-3.5 \mathrm{~mm}$.

Loc.: Nakagi, Minami-Izu machi, Shizuoka Prefecture ${ }^{2)}$, coll. K. SuzukI ${ }^{3)}$.

Distribution: Off Izu Penninsula and Sagami Bay.

\section{Suborder CARYOPHYLLIIDA VAUGHAN and WELLS Family CARYOPHYLLIIDAE GRAY \\ Subfamily Eusmilliinae MiLne Edwards and HaIME}

Genus Euphyllia DaNA

Genotype; Euphyllia glabrescens (CHAMISSO and EISENHARDT)

\section{Euphyllia sabiuraensis EGUCHI n. sp.}

(Pl. I, Fig. 5)

Euphyllia sp. (Japanese name: Ohnagarehanasango). Eguchi, 1972. On the corals of Sabiura, Kushimoto-cho, Wakayama Pref. (in Japanese). Marine Parks Journal, vol. 21, p. 9, Text-fig. right and left.

Corallum heavy, flabello-meandroid, standing on rather small base. Type specimen is a large fragment of $15 \times 15 \times 11 \mathrm{~cm}$. Valley continuous, sinuous, 15$18 \mathrm{~mm}$ deep; $23-25 \mathrm{~mm}$ wide at narrowest points, up to $44-70 \mathrm{~mm}$ at ends where it expands and inclines outwards so that wall becomes horizontal. Mural edge very thin, and fragile.

Septa thin, close together, 6-9 per $1 \mathrm{~cm}$, exsert almost evenly, some $1 \mathrm{~mm}$ over mural rim. Primaries $1.5 \mathrm{~mm}$ wide, their edges entire, deflected inside fossa, those from opposite sides coming very closely or overlapping if not for defliction. Septal surface smooth, except for few granules scattered here and there. Five to six smaller septa between two primaries. Costae thin, conspicuous throughout height of corallum, corresponding to every septa. Dissepiments large, well developed at wall.

Remarks: The present species has the widest valley among the known species of Euphyllia and the largest interval of septa $(6-9$ per $1 \mathrm{~cm})$. The nearest species, $E$.

1) Biological Laboratory, Imperial Household, 1968, The Hydrocorals and Scleractinian Corals of Sagami Bay. p.C 19; Maemi HanaokA, 1971, Poritidae. Graduation thesis in Science Course, Tokyo College of Domestic Science (M.S.) for 1971, p. 12.

2) Corals of the sea near South Izu, Shizuoka Prefecture, M. EguCHI, 1972, Marine Park Investigation Report, Shizuoka Prefecture, pp. 19-25.

3) Curator of the Marine Science Museum, Tokai University. 
fimbriata $^{4}$ and $E$. picteti ${ }^{5)}$, have more closely set septa, the latter can easily be distinguished by exsert septa and also by more crowded septa than in the present species. The most striking feature is the slender and cylindrical tentacles in the present species, by this characteristic it can easily be distinguished from E. fimbriata having spatulate tentacles (Text-figs. 1,2)

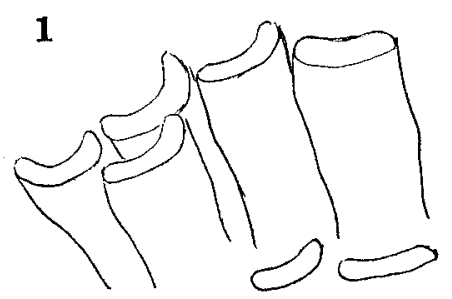

Fig. 1. Tentacles of Euphyllia fimbriata.

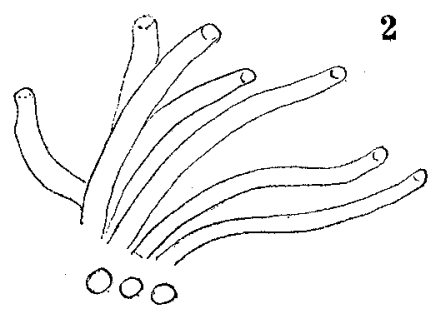

Fig. 2. Tentacles of Euphyllia sabiuraensis.

Euphyllia picteti BEDOT is treated by WeLLs ${ }^{6)}$ as synonymous with Catalaphyllia plicata (MILNE EDWARDS and HAIME) which has similar tentacles; however, specific distinction between these two species can be made easily by fewer septa per $1 \mathrm{~cm}$ in the former.

Dissepiment of the present species is narrower than in Catalaphyllia plicata. Polyps usually with fluorescent brilliant grayish green oral disc, tentacles brownish with green flecks, their tips light yellowish. While tentacles of Euphyllia fimbriata ${ }^{7}$ are spatulate, slightly concave in the middle part, and truncate at the tip.

Loc.: South West of Shirukoboshi off Sabiura, Kushimoto-cho, Wakayama Prefecture, 25 m. deep. Coll., T. Tatsuki, Date, Dec. 17, 1970.

Distribution: Only in Sabiura of the vicinity of the Kushimoto Marine Park.

\section{Family FLABELLIDAE BOURNE}

Genotype; Monomyces anthophyllum EHRENBERG

\section{Genus Monomyces EHRENBERG}

\section{Monomyces uchiuraensis EGUCHI ${ }^{8)}$}

(Pl. I, Figs. 1,2)

Corallum simple, large $(59 \times 43 \times 21,55 \times 42 \times 61,47 \times 35 \times 26 \mathrm{~mm})$, turbinate or subturbinate, with some tubular rootlets on outer side. Calice oval in shape, $45 \times 35$ $\mathrm{mm}$ in size, and $20 \mathrm{~mm}$ deep. Septa numerous (124 in type specimen), five cycles complete in hexameral plan, with some rudimentary 6th. Columella papillose.

4) Vaughan, T.W., 1918, Carnegie Inst. Wash. Pub. 213, p. 83, pl. 27, figs, 1,2.

5) Nemenzo, F., 1960, Nat. Appl. Sci. Bull. 17, p. 211, pl. 2, fig. 1.

6) Wells, J.W., 1972, Notes on Indo-Pacific Scleractinian Corals, pt. 7, Catalaphyllia, a New Genus of Reef Corals. Pacific Science, pp. 368-371.

7) Suzuki, K., 1972, Marine Life of Japan Seashore Animals, pl. 6. (in Japanese).

8) EguchI, M., 1972, Ann. Rep. Mar. Sci. Mus. Tokai Univ., No. 1, p. 159-162. 
Length of vacant rootlet $25 \mathrm{~mm}$ long at most, circular in cross-section. Wall epithecate, ornamented with concentric rings also the upper margin of calice.

Measurement of three specimens observed.

$\begin{array}{ccccc}\begin{array}{c}\text { Specimen } \\ \text { No. }\end{array} & \begin{array}{c}\text { Diameter of } \\ \text { calice }\end{array} & \begin{array}{c}\text { Depth of } \\ \text { calice }\end{array} & \begin{array}{c}\text { Height of } \\ \text { corallum }\end{array} & \begin{array}{c}\text { Number of septa } \\ \text { (according to size) }\end{array} \\ 42 & 59 \times 43 & 18 & 21 & 166(12+12+24+48+70) \\ 45 & 47 \times 35 & 20 & 26 & 124(11+11+22+43+37) \\ 48 & 55 \times 42 & 26 & 61 & 90(11+12+23+44)\end{array}$

Remarks: The specimen no. 45 was selected as the holotype, but three specimens agree well one another in measurements, the hightest sp. no. 48 bears 5 deep annulations probably showing rejuvenation traces. Monomyces typus (MILNE EDWARDs and HAIME) $)^{91}$ is the species related most closely to the present new species, but the former differs from the latter in having smaller and deeper calice and much higher corallum. The present species has rather well developed columella. Polyp is provided with crown of tentacles pink or reddish, elonate cylindrical and tapering. A beautiful figure of this form in natural color was published by Saburo Nishimura and Katsumi SuzUKi ${ }^{10}$ in May, 1971, under the name of Flabellum transversale, and the present writer proposed for it a new specific name Monomyces uchiuraensis EGUCH. ${ }^{13)}$

Monomyces palaoensis (YABE and EGUCHI) ${ }^{11}$ ) has also papillar columella but much lesser in size and with fewer septa. Monomyces niinoi (YABE and EGUCHI) ${ }^{12)}$, which had been the single species known from the Japanese waters, is much smaller in size, only $10 \times 11 \mathrm{~mm}$, and with 48 septa without columella.

Loc.: Awashima in Uchiura Bay, North West part of Suruga Bay, Shizuoka Prefecture, Central Japan. Coll, Katsumi SuzukI.

Distribution: Known only from the type locality.

\section{Suborder DENDROPHYLLIIDA VAUGHAN and WELLS} Family DENDROPHYLLIIDAE GRAY

\section{Genotype; Dendrophyllia ramea LinNaEus}

Genus Dendrophyllia DE BlainviLle

Dendrophyllia arbuscula var. compressa EGUGHI and SASAKI, n. var.

$$
\text { (Pl. I, Fig. 3) }
$$

Corallum branching in all direction, $6 \mathrm{~cm}$ high, basally covered with sponges and other organisms. Lateral bud arises nearly vertical to the principal calice. Branch

9) Milne Edwards and Haime, 1848, Monograph. turbinolides, p. 282, pl. 8, fig. 16.

10) Saburo Nishimura and Katsumi Suzuki, 1971, Common Seashore Animals of Japan in Color. Hoikusha, p. 11, pl. 4, fig. 1. This species is identified mistakenly with Flabellum transversale.

11) YABE and Eguchi, 1942, Foss. and Recent Simple Corals from Japan. p. 51.

12) Y $\mathrm{ABE}$ and EGUCHI, 1942, loc. cit. p. 50, pl. XII, figs. 6-7.

13) Kazuko InABA, 1971, Dec. 20, Fossil and Recent Hexacorals, pt. 2, Simple Corals. Graduation thesis in Science Course, Tokyo College of Domestic Science, pp. 42-59 (M. S. in Japanese). 
subcylindrical, much compressed, cross-section oblong, 9-11 $\mathrm{mm}$ in longer axis, 5.5-7 $\mathrm{mm}$ in shorter axis. Subturbinate in lateral view, being slightly narrowed towards base. Young buds are more circular, 5-6 $\mathrm{mm}$ in diameter. Septa 4 cycles, 6 of the lst cycle are larger and upper margin entire, slightly exsert above; laterally covered with small granulations, the arrangement of which is linear and at some angle to the vertical inner margin. Outer end of septa is slightly thickened and spongy in texture, otherwise septa are very thin.

Remarks: Calice is always much compressed, and in this respect the present variety is easily distinguishable from the typical species (Dendrophyllia arbuscula VAN DER HORST $)^{14)}$ which is known as a deeper water species. However, the present variety thrives on rather shallow rocky floors. ${ }^{15)}$ Polyps are reddish as in normal dendrophyllid corals and with cylindrical tentacles.

Loc.: Nakagi, Minami-Izu machi, Shizuoka Prefecture. Coll. K. SuzuKi.

Distribution: Known only from the type locality

\section{Australian Corals}

Suborder CARYOPHYLLIINA VAUGHAN and WELLS Family CARYOPHYLLIIDAE MiLNe EDWARds and HAIME

Subfamily Turbinoliinae MILne EdWARds and HAIME

Genus Platytrochus Milne Edwards and HaIME

Genotype; Platytrochus stokesi (LEA) Middle Eocene, Alabama

\section{Platytrochus compressus (TENISON WOODS)}

(Pl. I, Figs. 8-11)

Conocyatus compressus Tenison Woods, 1877, Linn. Soc. N.S.W., vol. 11, pp. 302-3, pl. V, fig. 1. Platytrochus compressus Dennant, 1904, Roy. Soc. South Australia, Trans. vol. 28, p. 4.

Corallum simple, wedge-shaped with small pointed stalk. Some 6 examined specimens from different hauls agree well with the descriptions and figures by TENISON Woods and also by DenNant. Corallum laterally much compressed and measures 7.6-9 $\mathrm{mm}$ broad, calice $5 \mathrm{~mm}$ in shorter diameter, $10 \mathrm{~mm}$ high, stalk 1-2.5 mm long; no epitheca; the characteristic costae are well shown in Figs. 9 and 11. This is a rather common ahermatypic coral in South Australia and Victoria.

Loc.: Pearson Is. Survey, St. F. Coll. J.E. WAtson, Jan. 11, 1969, associated with Pseudogorgia geoffroyi KöLlIKER and Isis sp. Investigator Strait, St. Y. 15.

Distribution: St. Vincent Gulf, Backstairs Passage, Investigator Straits, 15-22 fathoms, Port Stephens, N.S.W., and Pearson Islands, S. Australia.

14) Van Der Horst, C.J. 1922, Siboga Exped. Pt. 3, Mono. 16c, Eupsammidae. p. 53, p1. 8, fig. 6.

15) EguchI, 1972, Corals from Izu Penninsula and its near by (in Jap.); Tamiko SaSAKI, Study of Fossil and Recent Corals, Dendrophylliidae. Graduation thesis in Science Course, Tokyo College of Domestic Science, 1971 (M.S.) 


\title{
Suborder FAVIINA VAUGHAN and WeLlS \\ Family RHIZANGIIDAE D'ORBIGNY
}

Genotype; Culicia stellata DANA

\author{
Genus Culicia Dana
}

\section{Culicia hoffmeisteri SQUIRES}

(P1. I, Figs. 6,7)

Culicia tenella DANA; HoffmeISTER, 1933, Biol. Res. Fishing Exp. F.I.S. Endeavour, vol. 6, pl. 1, p. 11 , pl. 3 , figs. 1,2 .

Culicia rubeola Quoy and Gaimard, Dennant, 1904, Trans. and Proc. Roy. Soc. South Australia, p. 9. Culicia hoffmeisteri SQuires, 1966, Mem. Nat. Mus. Melbourne no. 27, p. 171, pl. 1, fig. 3.

Reptoid coral illustrated in Fig. $6(\times 3)$ and Fig. 7 agree well with the descriptions of $C$. hoffmeisteri in every respect. Diameter of calices varying from 1.4 to $1.8 \mathrm{~mm}$, septa $24-38$ in number.

Loc.: Investigator Strait, St. X 27. Coll. J.E. WATson. Date, Jan. 17, 1971

Distribution: Port Phillip, Kingston, and Investigator Strait, South Australia

\section{EXPLANATION OF PLATE I}

Figs. 1,2. Monomyces uchiuraensis Eguchr nat. size. 1 Calicular view, 2 Lateral view. Loc.: Awashima in Uchiura Bay, $20 \mathrm{~m}$.

Fig. 3. Dendrophyllia arbuscula var. compressa EGUCHI and SASAKI nov. var., nat. size. Upper view. Loc.: Nakagi, Minami-Izu machi, Shizuoka Pref.

Fig. 4. Alveopora japonica var. magna EGUCHI n., nat. size. Upper view. Loc.: Nakagi, Minami-Izu machi, Shizuoka Prefecture. Coll. K. Suzukr.

Fig. 5. Euphyllia sabiuraensis EGuchI n. sp., reduced $(\times 1 / 2)$. Loc.: Sabiura, Kushimoto machi, Wakayama Prefecture. Coll. T. TATsuki.

Figs. 6,7. Culicia hoffmeisteri SQUiREs. 6 Enlarged $(\times 3)$, calicular view. 7 Lateral view, nat. size. Loc.: Investigator Strait, St. X27. Coll. J.E. WATSON. Date; Jan. 17, 1971.

Figs. 8-11. Platytrochus compressus (TeNison WoODs), enlarged $(\times 3)$. 8, 10 Calicular view. 9, 11 Lateral view. Loc.: Investigator Strait, St. Y 15. Coll. J.E. WATSON. Date; Jan. 21, 1971. 
Proc. Second Internat. Symp. Cnidaria
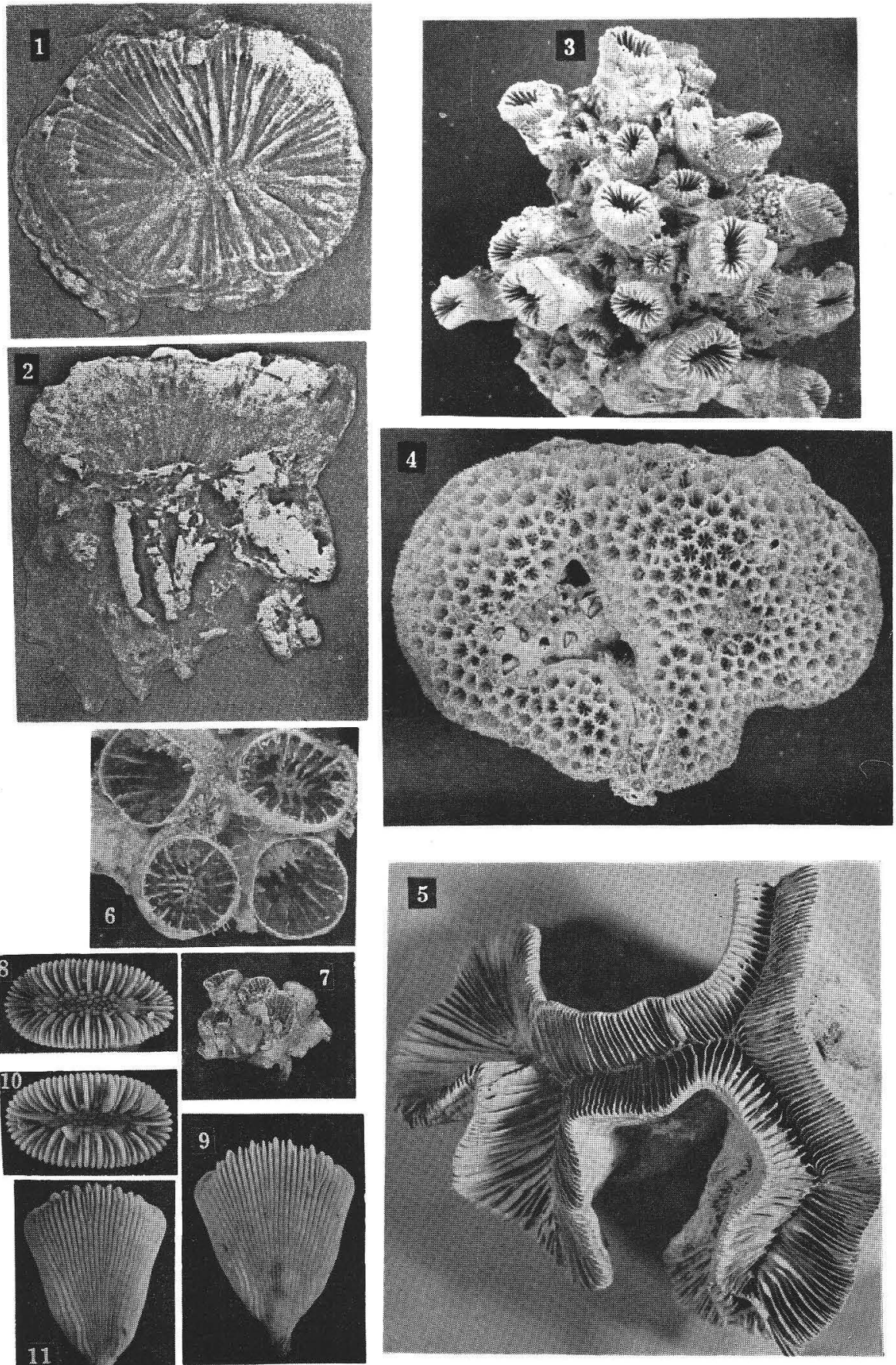

M. EGuchI: Some Corals from Japan and Australia 